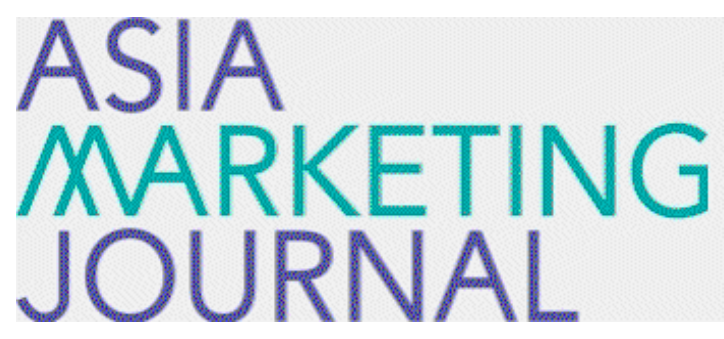

ASIA MARKETING JOURNAL

Volume 16 | Issue 1

Article 2

4-30-2014

\title{
Mediating Effects of Green Purchasing Capability on the Organizational Characteristics-Firm Performance Relationship
}

Soon Hong Min

Su Bin Im

Ta Tiana Kogan

Follow this and additional works at: https://amj.kma.re.kr/journal

Part of the Marketing Commons

\section{Recommended Citation}

Min, Soon Hong; Im, Su Bin; and Kogan, Ta Tiana (2014) "Mediating Effects of Green Purchasing Capability on the Organizational Characteristics-Firm Performance Relationship," Asia Marketing Journal: Vol. 16 : Iss. 1 , Article 2.

Available at: https://doi.org/10.53728/2765-6500.1525

This Article is brought to you for free and open access by Asia Marketing Journal. It has been accepted for inclusion in Asia Marketing Journal by an authorized editor of Asia Marketing Journal. 


\title{
Mediating Effects of Green Purchasing Capability on the Organizational Characteristics-Firm Performance Relationship*
}

\author{
Soonhong Min** \\ Subin $\mathrm{Im}^{* * *}$ \\ Tatiana Kogan****
}

\begin{abstract}
Despite heightened interest in and increased urgency surrounding the adoption of green business initiatives, firms seem to suffer from a limited understanding of the prerequisites and profit potentials of green strategies. Our proposed theoretical model suggests that green purchasing asa unique firm capability must be built on internal organizational characteristics (i.e., top management commitment to environmental management, inter-functional coordination, and performance evaluation and reward systems), and that it eventually helps a firm obtain positive financial performance. We offer some research propositions about potential causal relationships among key constructs that can be empirically tested in future research. We conclude the current study with implications for both managers and researchers.
\end{abstract}

Key words: environmental management, green purchasing capability, competitive advantage, financial performance

The modern business environment is characterized by a growing number of environmental regulations and legislation, combined with pressures from various stakeholders for ever higher environmental standards. It is evident that a firm's green purchasing activities bring the company financial benefits by cutting costs such as materials cost and waste disposal cost and/ or by increasing revenue. For example, Wal-Mart saved $\$ 2.4$ million a year by eliminating excessive packaging for inbound shipping (Gunter 2006). For another example, Mountain Equipment Co-op, the largest retail co-operative in Canada, saved landfill costs by $\$ 115$ in Canadian dol-

\footnotetext{
* This paper is for the research note.

** Yonsei University Yonsei School of Business(sminscm@yonsei.ac.kr)

*** Yonsei University Yonsei School of Business(imsubin@yonsei.ac.kr), Corresponding Author

**** Yonsei University Yonsei School of Business(Tatiana@daelim.co.kr)
} 
lars per ton per year by reducing packaging materials used for inbound shipping (Metro Vancouver Head Office, 2014). With regard to green purchasing, we find that insufficient research deals with the impact of a firm's capability to implement green purchasing on its financial performance as well as potential organizational antecedents to influence developing that capability.

The objective of this study is to propose a theoretical framework in which green purchasing capability mediates the relationship between a firm's organizational characteristics and its business performance. With our proposed theoretical model, we explicate three organizational determinants of green purchasing capability: top management commitment to environmental management, interfunctional coordination, and performance evaluation and reward systems. We also include financial performance as an essential outcome of this capability. In turn, we offer propositions about the specific causal relationships among green purchasing capability, its antecedents, and a consequence. Finally, we conclude with implications of this model for both managers and future researchers.

\section{Theoretical Background: Green Purchasing}

As a set of activities, green purchasing is part of environmental management, or the firm's efforts to reduce the impacts of its business operations on the environment (Cramer 1998). Carter et al. (2000) propose that green purchasing activities help the firm design its products for reuse, recycling, and disassembly by suggesting alternative sources of supply by suppliers in product design. Thus, we propose that green purchasing activities comprise assessments and monitoring of the environmentally sustainable operations of suppliers.

In line with the resource-based view (RBV) of the firm (Barney 1991), we propose that green purchasing constitutes a firm's critical capability that can be leveraged to achieve a competitive advantage(cf. Jung, Kim, and Ryou 2008). The competitive advantage gained through green purchasing results in superior business performance. Green purchasing capability is a firm's unique ability to make environmentally conscious purchasing decisions that promote waste reduction and resource conservation in various forms, such as input reduction and output reuse and recycling, throughout the supply chain (Carter and Carter 1998; Min and Galle 2001). In practice, it is not unusual for purchasing managers to choose less environmentally friendly materials over green materials, because of the pressures on them to cut costs in the short term. This is so because managers are not knowledgeable to think means of balancing internal cost reduction need and external environmental protection requirement. In this re- 
gard, a purchasing manager's expertise with green purchasing constitutes tacit knowledge that competitors cannot imitate easily (Barney 1995). In addition, green purchasing activities require cross-functional knowledge and coordination skills to mediate different priorities e.g., cost reduction, brand image building, new product development - of different functions and to subsequently assess trade-offs between costs and profits. Consequently, the talent pool to find capable purchasing managers is limited and hard to replace existing knowledgeable managers. In summary, we consider green purchasing a firm's unique capability, because it is valuable, rare, difficult to imitate and substitute, and socially complex, and because it can lead to a sustainable competitive advantage (Barney 1991).

\section{Theoretical Model Development and Propositions}

We develop an integrative theoretical framework of green purchasing based on Day and Wensley's (1988) source - position - performance (SPP) framework. We propose green purchasing capability as a positional mediator that explains the relationships between selected organizational characteristics and financial performance. We argue organizational characteristics (i.e., top management commitment to environmental management, interfunctional coordination, and performance evaluation and reward systems) as sources influence green purchasing capability as a positional advantage, which then produces positive financial outcomes as performance. We present the theoretical model in Figure 1.

〈Figure 1〉 A Theoretical Model of Green Purchasing Capability

\section{Top Management \\ Commitment to \\ Environmental \\ Management}

\section{Inter-functional Coordination}

\footnotetext{
Performance

Evaluation and

Reward Systems
}

P1

P2 $\begin{gathered}\text { Green } \\ \begin{array}{c}\text { Purchasing } \\ \text { Capability }\end{array}\end{gathered} \quad$ P4 $\quad \begin{gathered}\text { Financial Firm } \\ \text { Performance }\end{gathered}$

P3 


\subsection{Facilitators of Green Purchasing Capability}

\subsubsection{Top Management Commitment to Environmental Management}

We define top management commitment to environmental management as the proactive attitude among the top management team toward implementing green practices, through an embodiment of company-wide goals, values, and practices that are directly linked to promoting environmental management (Cramer 1998; Drumwright 1994). Top management teams have the authority and control to influence their firms' adoption of environmentally friendly behavior (Griffin, Rafferty, and Mason 2004; Rojsek 2001). For example, at Homeplus (formerly Samsung Tesco), a Korean retailor, top management team that consists of the company's CEO and directors steer the company's sustainability strategy (Kim, Ahn, and Lim 2008). Thus, top management commitment to environmental management should represent a vital facilitator of environmentally friendly firm $\mathrm{ca}^{-}$ pabilities, including a green purchasing capability (Rice 2003; Walton et al. 1998). We posit:

P1: Top management commitment to environmental management facilitates the firm's green purchasing capability.

Interfunctional coordination. We define inter- functional coordination as the synchronized efforts of different functions within the firm to pursue value creation for customers (Narver and Slater 1990). Interfunctional coordination should be essential to the development of green purchasing capability because a firm with high interfunctional coordination can effectively overcome organizational inertia against adopting green purchasing criteria and the potentially increased expenditures. In order to overcome the challenges against the adoption of green purchasing practice, different functions within a particular organization have to not only interact and cooperate systematically with each other but also internally align for environmental goals. Thus,

\section{P2: A firm's interfunctional coordination fa- cilitates its green purchasing capability.}

\subsubsection{Performance Evaluation and Reward Systems}

We define performance evaluation and reward systems as a firm's formal systems that evaluate employees and delineate the incentive programs for their employees, according to the achievement of environmental goals (e.g., Aime, Meyer, and Humphrey 2010; Sethi 2000; Wei and Atuahene-Gima 2009). Carter et al. (1998) propose that personnel engaged in green purchasing activities benefit from instructive evaluations that monitor and control whether their activities correspond with the firm's environ- 
mental goals. The firm's evaluation and reward systems, thus, promotes environmental consciousness and also facilitates the development of a green purchasing capability among various internal stakeholders. Thus, we hypothesize:

\section{P3: A firm's performance evaluation and re- ward systems directed toward environ- mental management facilitate its green purchasing capability.}

\subsection{Consequence of Green Purchasing}

To assess the impact of green purchasing capability, we choose financial performance, defined as the monetary outcomes obtained from normal businesses (Gonzales-Benito and GonzalesBenito 2005: Hart and Ahuja 1996; Russo and Fouts 1997). Min and Galle (1997) argue that environmentally conscious purchasing can improve a firm's financial position by reducing resource use, material disposal, and liabilityrelated costs, as well as improving the public image of the firm. In reality, top management cannot justify any investment in the firm's environmental management unless it is able to show shareholders projected financial benefits in the long term. Rao (2002) indicated that green purchasing capability that helps a firm use green and environmentally sustainable material leads to lower energy consumption of and lower amount of waste, which in turn should lead to better financial outcomes. Therefore, we hy- pothesize:

\author{
P4: A firm's green purchasing capability en- \\ hances its financial performance.
}

\section{Implications}

Our study focuses on developing a theoretical model of green purchasing capability that can give firms a competitive edge in the sustainable development era. With our proposed theoretical framework, we explore three key internal facilitators of green purchasing capability and the financial performance that results from it.

Drawing on the RBV, we explicate how a firm's capability to manage green purchasing practices enhances its competitive advantage and thus can lead to superior performance. With the source-position - performance framework, we also explain the important mediating role of green purchasing capability in the relationship between organizational characteristics (i.e., top management's commitment to environmental management, interfunctional coordination, and performance evaluation and reward systems) and the firm's bottom line.

\subsection{Managerial Implications}

Our study has two notable managerial implications. First, the descriptions of the impact of green 
purchasing capability on a firm's financial performance provide an answer to the question of whether it is worthwhile for firms to invest time, money, and efforts to build their green purchasing capacity.

Second, our exploration of the relationships of the strategic, internally manageable factors as facilitators of green purchasing capability answers the question of how organizational culture nurtures a green purchasing capability and accordingly produces a competitive advantage in the market. We clarify that top management commitment is a make-or-break determinant of green purchasing capability, considering the organizational complexity and dilemma between immediate cost savings and long-term profit potential that accompany the implementation of green purchasing. Regarding interfunctional coordination, firms engaged in green purchasing need to pay sufficient attention to organizationwide coordination across different functions, to ensure that experts from different functional backgrounds can help one another implement environmentally sustainable practices successfully in purchasing decisions. With regard to performance evaluation and rewards systems, firms must monitor, control, and enhance company-wide efforts to achieve environmental goals and standards, and thus improve the resulting enhancement to firm performance through green purchasing.

\subsection{Research Implications}

We hope the suggested theoretical framework sheds light on the emergence of new types of dynamic capabilities in general and green purchasing capability in specific, as a viable means firms can use to compete in the ever- evolving sustainable economy (Teece et al. 1997). The theoretical development in our model remains subject to testing by empirical research that confirms or disconfirms our propositions, or modifies them if necessary. We thus call for continued research on green purchasing capability.

\subsection{Limitations and Future Research Directions}

Our study is limited to providing a conceptual framework for the mediating effects of green purchasing capability. Future research should empirically test the proposed model by collecting and analyzing the data. In addition, further research is called for to examine potential moderating effects of environmental characteristics (e.g., market uncertainty and technological turbulence).

〈Received November 18, 2013〉

〈Revised March 1, 2014〉

〈Accepted March 3, 2014〉 


\section{References}

Aime, F., Meyer, C. J., and Humphrey, S. E. (2010), "Legitimacy of Team Rewards: Analyzing Legitimacy as a Condition for the Effectiveness of Team Incentive Designs," Journal of Business Research, 63(1), 60-6.

Barney, J. (1991), "Firm Resources and Sustained Competitive Advantage," Journal of Management, 17, 99-120.

(1995), "Looking Inside for Competitive Advantage," Academy of Management Executive, 9(4), 49 - 61

Carter, C.R., Ellram, L. M., and Ready, K. (1998), "Environmental Purchasing: Benchmarking Our German Counterparts," International Journal Purchasing and Materials Management, 28-38. and Carter, J.R. (1998), "Interorganizational Determinants of Environmental Purchasing: Initial Evidence from the Consumer Products Industry," Decision Sciences, 29(3), 659-84.

Kale, R., and Grimm, C. M. (2000), "Environmental Purchasing and Firm Performance: An Empirical Investigation," Transportation Research Part E: Logistics and Transportation Review, 36(3), 219-28.

Cramer, J.(1998), "Environmental Management: from 'Fit' to 'Stretch'," Business Strategy and the Environment, 7, 162-72.

Day, G. S., and Wensley, R. (1988), “Assessing
Advantage: A Framework for Diagnosing Competitive Superiority," Journal of Marketing, $1-20$.

Drumwright, M. (1994), "Socially Responsible Organizational Buying: Environmental Concern as a Non-economic Buying Criterion," Journal of Marketing, 58, 1-19.

Gonzalez-Benito, J., and Gonzalez-Benito, O. (2005), "Environmental Proactivity and Business Performance: An Empirical Analysis," Omega, 33, 1-15.

Griffin, M., Rafferty, A., and Mason, C. (2004), "Who Started This? Investigating Different Sources of Organizational Change," Journal of Business and Psychology, 18(4), 555-70. Gunther, M. (2006), “The Green Machine," Fortune Magazine, http://money.cnn.com/ magazines/fortune/fortune_archive/2006/ 08/07/8382593/index.htm.

Hart, S. and G. Ahuja, (1996), "Does it Pay to be Green? An Empirical Examination of the Relationship between Emission Reduction and Firm Performance," Business Strategy and the Environment, 5, 30-7.

Hunt, S.D. and Morgan, R.M. (1995), “The Comparative Advantage Theory of Competition," Journal of Marketing, 59(April) 1-15.

Metro Vancouver Head Office (2014), "Case Study Retail: Mountain Equipment Co-op," Smart Steps, http://www.metrovancouver. org/smartsteps/bestpractices/Case\%20Studies /CaseStudy-Retail.pdf 
Jung, H., Kim, Y., and Ryou S. (2008), "How Internal Capability and External Collaboration Influence the Technical Development Using Information Processing in Automotive Part Industry," Asia Marketing Journal, 9 (4), 117-144.

Kim, Y., Ahn, K., and Lim, Y. (2008), “Corporate Sustainability Management of Sansung Tesco through Corporate Responsibility Activities," Asia Marketing Journal, 10 (3), 147-168.

Min, H., and Galle, W. P. (1997), "Green Purchasing Strategies: Trends and Implications," Journal of Supply Chain Management, 33 (3), 10-7.

(2001), “Green Purchasing

Practices of US Firms," International Journal of Operations and Production Management, 21(9), 1222-38.

Narver, J.C. and Slater S.F. (1990), "The Effect of a Market Orientation on Business Profitability," Journal of Marketing, 54(4), 20-36.

Rice, S.(2003), "Commitment to Excellence: Practical Approaches to Environmental Leadership," Environmental Quality Management, 12 (4), 9-22.

Rojsek I. (2001), "From Red to Green: towards Environmental Management in the Country in Transition," Journal of Business Ethics, 33, 37-50.

Russo, MV. and Fouts, P.A. (1997), "A ResourceBased Perspective on Corporate Environmental Performance and Profitability," Academy of Management Journal, 40, 534-59. Sethi, R. (2000), "Superordinate Identity in Cross-Functional Product Development Teams: Its Antecedents and Effect on New Product Performance," Journal of the Academy of Marketing Science, 28 (3), 330-41.

Teece, D. J., Pisano, G., and Shuen, A. (1997), "Dynamic Capabilities and Strategic Management," Strategic Management Journal, 18(7), 509-33.

Walton, S. V., Handfield, R. B., and Melnyk, S. A. (1998), "The Green Supply Chain: Integrating Suppliers into Environmental Management Processes," International Journal of Purchasing and Materials Management, 32 (4), 2-11.

Wei, Y.S. and Atuahene-Gima, K. (2009), “The Moderating Role of Reward Systems in the Relationship between Market Orientation and New Product Performance in China," International Journal of Research in Marketing, 26(2), 89-96. 